\title{
Kriteria Dasar Infrastruktur Permukiman Pada Daerah Nelayan (Contoh Kasus Daerah Nelayan Kota Sorong)
}

\author{
Asriadi Asriadi ${ }^{1)}$, Wilis Sutiono ${ }^{2)}$ \\ 1), 2) Program Studi Teknik Sipil Universitas Muhammadiyah Sorong \\ J1 Pendidikan No 27 Kota Sorong \\ Email : asriadisoq89@gmail.com
}

\section{Pengertian Permukiman Nelayan}

Menurut ST. Khadija arti kata Nelayan terbagi dalam dua pengertian nelayan yaitu :

1. Nelayan Sebagai Subyek/Orang; merupakan sekelompok masyarakat manusia yang memiliki kemampuan serta sumber kehidupan disekitar pesisir pantai.

2. Nelayan sebagai predikat/pekerjaan; suatu sumber penghasilan masyarakat yang berkaitan erat dengan sektor perikanan dan perairan (laut dan sungai).

Permukiman nelayan adalah merupakan lingkungan tempat tinggal dengan sarana dan prasarana dasar yang sebagian besar penduduknya merupakan masyarakat yang memiliki pekerjaan sebagai nelayan dan memiliki akses dan keterikatan erat antara penduduk permukiman nelayan dengan kawasan perairan sebagai tempat mereka mencari nafkah, meskipun demikian sebagian dari mereka masih terikat dengan daratan.

Secara umum permukiman nelayan dapat digambarkan sebagai suatu permukiman yang sebagian besar penduduknya merupakan masyarakat yang memiliki pekerjaan sebagai nelayan. Sedangkan pekerjaan nelayan itu sendiri adalah pekerjaan yang memiliki ciri utama adalah mencari ikan di perairan. Sedangkan menurut Peraturan Menteri Negara Perumahan Rakyat Republik Indonesia Nomor 15/Permen/M/2006 Tentang Petunjuk Pelaksanaan Penyelenggaraan Pengembangan Kawasan Nelayan, perumahan kawasan nelayan untuk selanjutnya disebut kawasan nelayan adalah perumahan kawasan khusus untuk menunjang kegiatan fungsi kelautan dan perikanan.

Pada perkembangannya kampung-kampung nelayan berkembang semakin padat dan tidak tertib karena pertumbuhan penduduk alami dan urbanisasi. Kriteria fisik lingkungan kawasan permukiman nelayan sebagai berikut: (Depertemen Pekerjaan Umum)

1. Tidak berada pada daerah rawan bencana

2. Tidak berada pada wilayah sempadan pantai dan sungai

3. Kelerengan : $0-25 \%$

4. Orientasi horizontal garis pantai : $>60^{\circ}$

5. Kemiringan dasar pantai : terjal - sedang 
6. Kemiringan dataran pantai : bergelombang - berbukit

7. Tekstur dasar perairan pantai : kerikil - pasir

8. Kekuatan tanah daratan pantai : tinggi

9. Tinggi ombak signifikan : kecil

10. Fluktuasi pasang surut dan arus laut : kecil

11. Tidak berada pada kawasan lindung

12. Tidak terletak pada kawasan budidaya penyangga, seperti kawasan mangrove.

\section{Karakteristik Kehidupan Masyarakat Nelayan}

\subsection{Kehidupan Masyarakat Nelayan Ditinjau Dari Aspek Sosial}

Hubungan sosial yang terjadi dalam lingkungan masyarakat nelayan adalah akibat interaksi dengan lingkungannya. Adapun ciri sosial masyarakat nelayan sebagai berikut:

1. Sikap kekerabatan atau kekeluargaan yang sangat erat.

2. Sikap gotong royong/paguyuban yang tinggi.

Kedua sikap telah banyak mewarnai kehidupan masyarakat nelayan yang pada umumnya masih bersifat tradisional. Lahirnya sikap ini sebagai akibat dari aktivitas nelayan yang sering meninggalkan keluarganya dalam kurun yang waktu cukup lama, sehingga timbul rasa keterkaitan serta keakraban yang tinggi antara keluarga-keluarga yang ditinggalkan untuk saling tolong menolong.

\subsection{Kehidupan Masyarakat Nelayan Ditinjau Dari Aspek Budaya}

Beberapa hal yang telah membudaya dalam masyarakat nelayan adalah kecenderungan hidup lebih dari satu keluarga dalam satu rumah atau mereka cenderung untuk menampung keluarga serta kerabat mereka dalam waktu yang cukup lama, hal ini menyebabkan sering dijumpai jumlah anggota keluarga dalam satu rumah melebihi kapasitas daya tampung, sehingga ruang gerak menjadi sempit dan terbatas. Dan dampaknya itu pula, mereka cenderung untuk memperluas rumah tanpa terencana. Masyarakat nelayan pada umumnya mempunyai tingkat pendidikan yang rendah, menyebabkan kurangnya pengetahuan mereka sehingga menghambat kemajuan nelayan sendiri, antara lain sulitnya bagi pemerintah untuk memberi bantuan dalam bentuk penyuluhan maupun modernisasi peralatan (Mubyarto;1985).

\section{Kehidupan Masyarakat Nelayan Ditinjau Dari Aspek Ekonomi}


Usaha perikanan banyak tergantung pada keadaan alam, sehingga pendapatan nelayan tidak dapat ditentukan. Tingkat penghasilan nelayan umumnya dibagi atas dua:

3.1 Penghasilan bersih yang diperoleh selama melaut jika seorang "sawi" maka besar pendapatannya sesuai dengan kesepakatan.

3.2 Penghasilan sampingan yaitu penghasilan yang diperoleh dari pekerjaan tambahan, baik pekerjaan itu didapat ketika jadi buruh, bertani dan berdagang maupun pekerjaan atau kerajinan dalam mengelola hasil laut lainnya.

\section{Perkembangan Kota dan Dampaknya Terhadap Penyediaan Prasarana Wilayah}

Perkembangan kota yang merupakan bagian dari pembangunan yang dilakukan oleh pemerintah pada dasarnya bukan hanya merupakan kemauan dari pemerintah sendiri, tetapi juga terjadi akibat dari perkembangan penduduk dan semakin banyaknya kebutuhan dari masyarakat kota itu sendiri. Tingkat pertumbuhan penduduk yang tinggi dan terbatasnya ruang yang tersedia terutama bagi Kota-Kota pusat pengembangan wilayah dapat menimbulkan persoalan-persoalan diantaranya adalah sebagai berikut:

1. Kebutuhan ruang bagi pengembangan sarana dan prasarana kota untuk memenuhi kebutuhan penduduknya dan segala tuntutannya pada masa yang akan datang tidak dapat terpenuhi,

2. Ekspansi kegiatan perkotaan di wilayah pinggiran yang tidak sesuai dengan pola kebijaksanaan pengembangan kota telah menimbulkan pola peruntukan lahan yang tidak teratur,

3. Menurunnya kualitas lingkungan kehidupan perkotaan akibat menurunnya tingkat pelayanan yang ditinjau dari segi rasio antara jumlah sarana dan prasarana yang ada dengan jumlah penduduk.

\subsection{Ketersediaan Infrastruktur permukiman nelayan}

Infrastruktur adalah Fasilitas-fasilitas fisik yang dikembangkan atau dibutuhkan oleh agen-agen publik untuk fungsi-fungsi pemerintahan dalam penyediaan air bersih, tenaga listrik, pembuangan limbah, transportasi dan pelayanan similar untuk memfasilitasi tujuan-tujuan ekonomi dan sosial.

\subsection{Prasarana Air Bersih Sebagai Prasarana Fisik Kota}


Sarana dan prasarana wilayah menurut Bourne, berperan dalam pembangunan bentuk fisik kota dan kualitas hidup di dalamnya. Semua sarana dan prasana tersebut dapat meningkatkan kualitas hidup manusia, namun tidak semua sarana dan prasarana kota dapat berperan dalam membangun dan menentukan bentuk fisik kota. Hanya prasarana yang membentuk sistem jaringan yang dapat membangun dan menentukan bentuk fisik kota. Dengan demikian, dapat disimpulkan bahwa sistem penyediaan air bersih yang merupakan bentuk prasarana dengan sistem jaringan dapat mengarahkan dan membangun bentuk fisik suatu wilayah.

Menurut Model Penyiapan Program Pembangunan Prasarana dan Sarana Dasar Perkotaan Tahun 1994, pemenuhan kebutuhan air bersih suatu daerah perkotaan dapat dianalisis berdasarkan:

1. Faktor Penduduk.

2. Tingkat Pelayanan

\subsection{Sistem Pelayanan Air Bersih Perkotaan}

Menurut Noerbambang, ada 4 komponen utama yang termasuk kedalam sistem penyediaan air bersih, yaitu:

1. Unit pengumpul/intake air baku (collection or intake work).

2. Unit pengolahan air/sistem produksi (purification or treatment work).

3. Unit transmisi/sistem transmisi (transmision work)

4. Unit distribusi/sistem distribusi (distribution work).

\subsection{Pemanfaatan Sumber Daya Air}

pemenuhan kebutuhan air bersih pada suatu wilayah dapat dilakukan dengan cara pemanfaatan sumber daya air, yaitu:

1. Mengalirkan air dari sumbernya ke tempat pengguna atau pelayanan umum. Dimana, pelayanan dilakukan oleh pemerintah kota setempat yang pelaksanaannya dilakukan oleh Perusahaan Daerah Air Minum (PDAM) dengan memanfaatkan sumber air baku yang ada dan diolah serta didistribusikan kedaerah pelayanan atau pelanggan.

2. Mengusahakan sendiri dengan menggali sumur. Penggalian sumur melalui sumur gali atau sumur bor banyak dilakukan oleh penduduk untuk memenuhi kebutuhan domestik, niaga dan industri.

\subsection{Sarana Permukiman Nelayan}

1. Tempat Pelelangan Ikan (TPI) 
Tempat pelelangan ikan (TPI) adalah tempat jual beli ikan dengan sistem lelang dimana terdapat kegiatan menimbang, menempatkan pada keranjang-keranjang dengan jenis-jenisnya atau digelar di lantai siap untuk dilelang, kemudian pelelangan lalu pengepakan dengan es untuk keranjang/peti ikan yang sudah beku.

2. Tambatan Perahu

Tempat penambatan perahu adalah tempat perahu-perahu bersandar / parkir sebelum dan sesudah bongkar muat ikan. Biasanya berdekatan dengan TPI. Fungsi tambatan perahu sebagai tempat untuk mengikat perahu saat berlabuh dan tempat penghubung antara dua tempat yang dipisahkan oleh laut, sungai maupun danau.

\subsection{Prasarana Permukiman Nelayan}

Prasarana adalah kelengkapan dasar fisik suatu lingkungan yang pengadaannya memungkinkan suatu kawasan permukiman nelayan dapat beroperasi dan berfungsi sebagaimana mestinya, seperti : jaringan air bersih dan air limbah, jaringan drainase, jaringan persampahan, dan jaringan jalan.

1. Jaringan Jalan

- Jalan Setapak

- Jalan Lokal

- Jalan Lingkungan

2. Jaringan Air Limbah / Air Kotor

Limbah adalah air bekas buangan yang bercampur kotoran, air bekas/air limbah ini tidak diperbolehkan dibuang ke sembarangan / dibuang keseluruh lingkungan, tetapi harus ditampung kedalam bak penampungan.

Limbah adalah kotoran dari masyarakat dan rumah tangga dan juga berasal dari industri, air tanah, air permukaan serta buangan lainnya. Dengan demikian air buangan ini merupakan hal yang bersifat kotoran umum.

3. Jaringan Drainase

drainase berasal dari bahasa inggris, drainage mempunyai arti mengalirkan, menguras, membuang, atau mengalihkan air. Dalam bidang teknik sipil, darinase secara umum dapat didefenisikan sebagai suatu tindakan teknis untuk mengurangi kelebihan air irigasi dari suatu kawasan/lahan, sehingga fungsi kawasan/lahan tidak terganggu. Drainase dapat juga diartikan sebagai usaha mengontrol kualitas air tanah dalam kaitannya dengan sanitasi. Jadi drainase menyangkut tidak hanya air permukaan tapi juga air tanah. 
4. Jaringan Persampahan

Sampah adalah segala sesuatu yang tidak lagi dikehendaki oleh yang punya dan bersifat padat. Sampah ini ada yang mudah membusuk dan ada pula yang tidak mudah membusuk. Yang membususk terutama terdiri dari zat-zat organik seperti sisa makanan, sedangkan yang tidak mudah membusuk dapat berupa plastik, kertas, karet, logam dan sebagainya.

5. Jaringan air bersih

Untuk memenuhi kebutuhan air bersih pada suatu kawasan permukiman maka adapun kriterianya adalah sebagai berikut :

1. Pengambilan air baku diutamakan dari air permukaan;

2. Kebutuhan air rata - rata 100 liter/orang/hari;

3. Kapasitas minimum sambungan rumah 60 liter/orang/hari dan sambungan kran umum 30 liter/orang/hari. 
Beberapa Contoh

Kriteria Dasar Infrastruktur Permukiman

Pada Daerah Nelayan di Kota Sorong
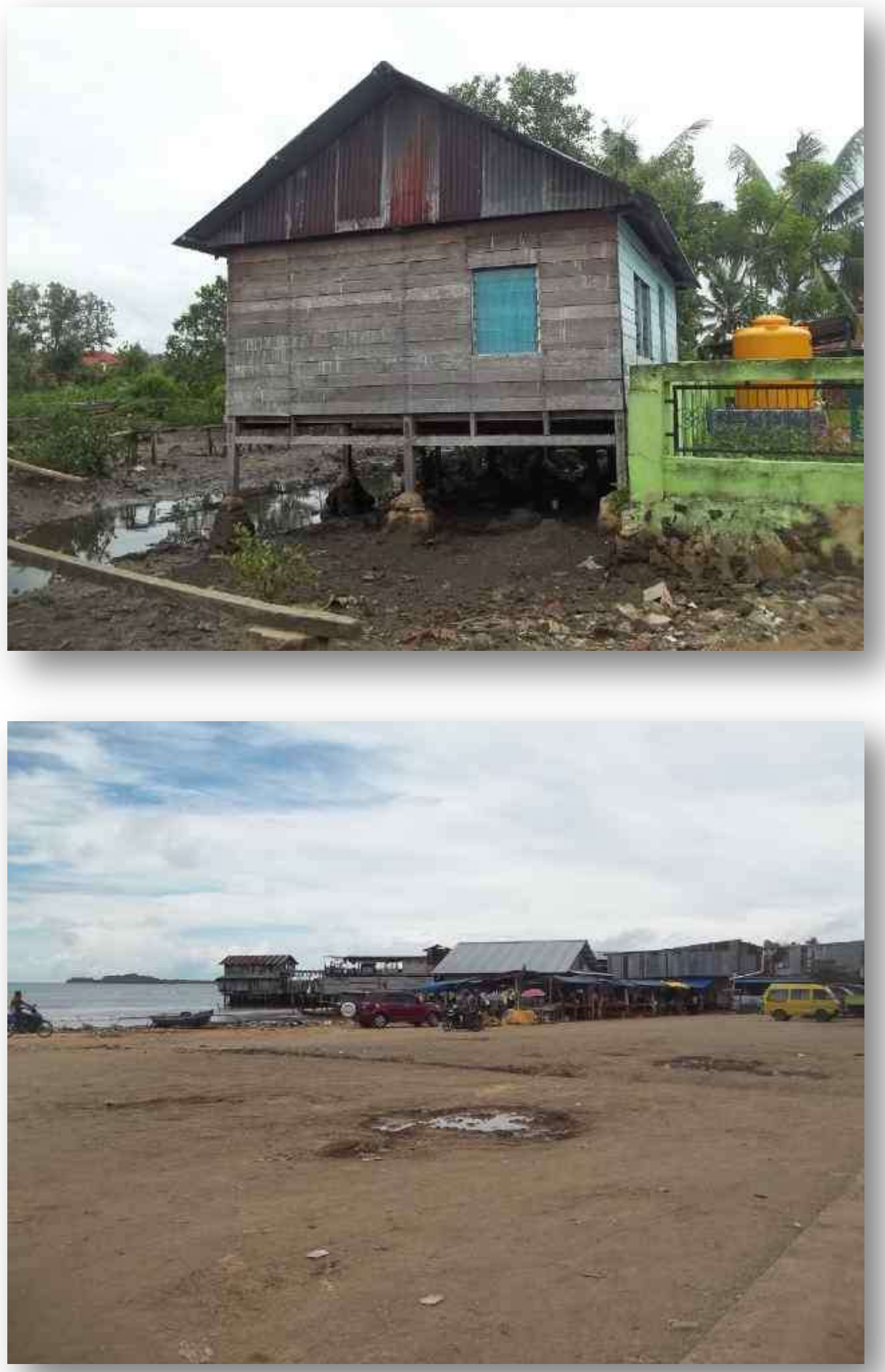

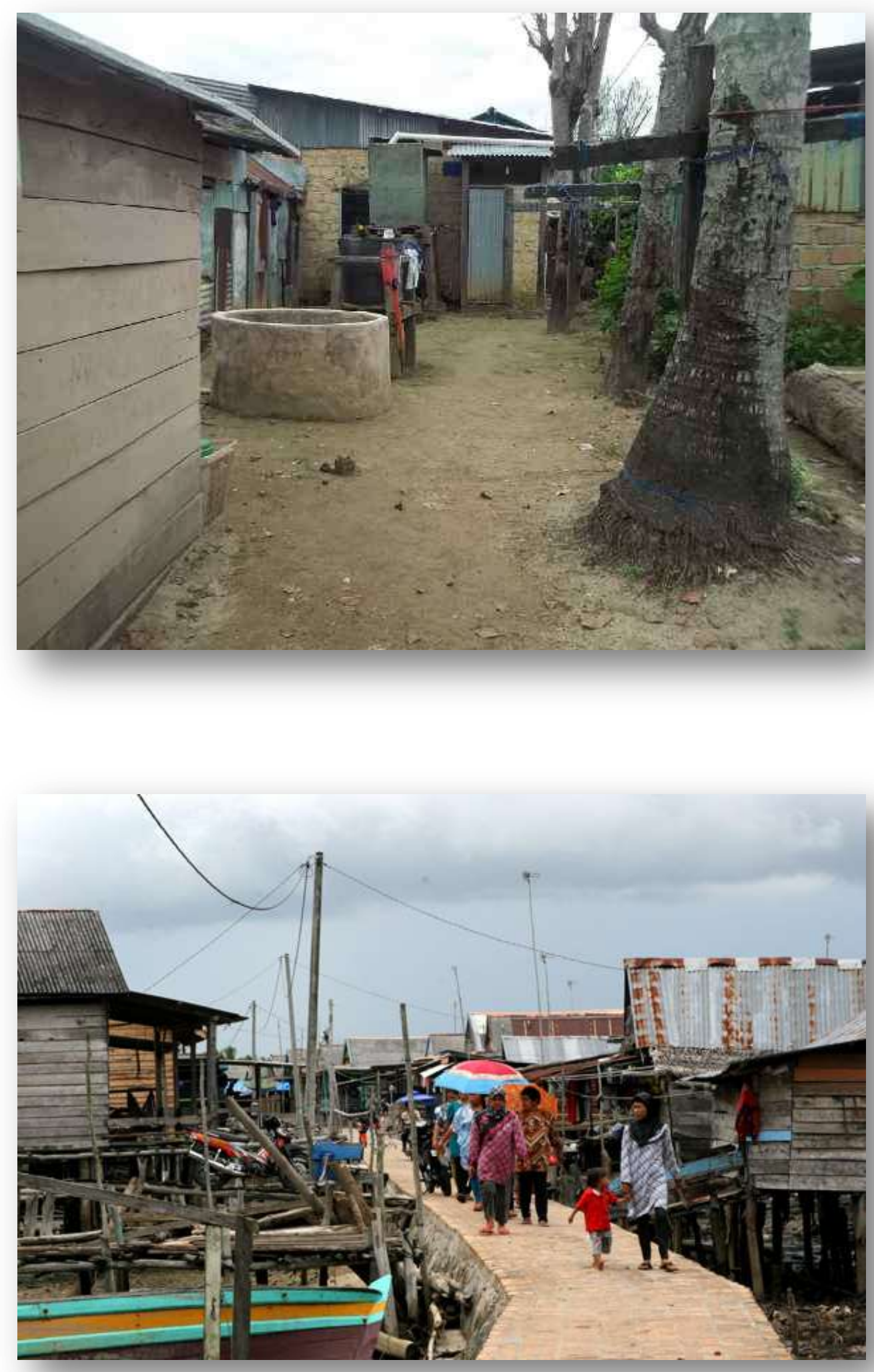